\title{
Electrochemical System for Determination of Esmolol Hydrochloride Using Square Wave Adsorptive Stripping Voltammetry
}

\author{
Nawal A. Alarfaj, Maha F. El-Tohamy ${ }^{\dagger^{*}}$ \\ Department of Chemistry, College of Science, King Saud University, P.O. Box 22452, Riyadh 11495, \\ Saudi Arabia \\ $\dagger$ Parmanent address: General Administration and Medical Affairs, Zagazig University, Egypt \\ *E-mail: star2000star@gmail.com
}

doi: $10.20964 / 110402709$

Received: 27 January 2016 / Accepted: 19 February 2016 / Published: 1 March 2016

\begin{abstract}
A simple, validated, sensitive and reliable electrochemical method for determination of esmolol hydrochloride (ESM) has been described. The cathodic behavior of ESM onto a hanging mercury drop electrode (HMDE) was evaluated using phosphate buffer of $\mathrm{pH}$ 7.2. The square wave adsorptive stripping voltammetric (SW-AdSV) method exhibited a peak current over a concentration range of $1.0 \times 10^{-8}-1.0 \times 10^{-4} \mathrm{~mol} \mathrm{~L}^{-1}(\mathrm{r}=0.9992)$. The low limits of detection and quantification were evaluated as $5.0 \times 10^{-9} \mathrm{~mol} \mathrm{~L}^{-1}$ and $1.0 \times 10^{-8} \mathrm{~mol} \mathrm{~L}^{-1}$, respectively. Method applications were concerned with the detection of ESM in its injections and biological samples. The recoded results were calculated in the term of percentage recoveries and they were $99.8 \pm 0.2$ for ESM injection, while for spiked serum and urine was found to be $98.8 \pm 0.7$ and $98.9 \pm 1.1$, respectively. The introduced method was validated and the data were assessed using t-student's test and F-test. Compatible results were recorded with those obtained from other published methods.
\end{abstract}

Keywords: Esmolol hydrochloride; Voltammetric determination; Pharmaceutical preparations; Biological fluids; Adsorptive stripping voltammetry

\section{$\underline{\text { FULL TEXT }}$}

(C) 2016 The Authors. Published by ESG (www.electrochemsci.org). This article is an open access article distributed under the terms and conditions of the Creative Commons Attribution license (http://creativecommons.org/licenses/by/4.0/). 